\title{
Socio-Economic Status and Benefits of Agricultural Interventions of Tribal Farmers in West Garo Hills of Meghalaya, India
}

\author{
Lakshmi Dhar Hatai ${ }^{\text {* }}$ and K. Noren Singh ${ }^{2}$ \\ ${ }^{1}$ Central Agricultural University (Imphal), College of Community Science, Tura, India \\ ${ }^{2}$ College of Post Graduate Studies in Agricultural Sciences, Umiam, Meghalaya, India \\ *Corresponding author:
}

\begin{tabular}{|l|}
\hline Ke y w or d s \\
$\begin{array}{l}\text { Socio-Economic, } \\
\text { Tribal, Agricultural } \\
\text { Intervention, } \\
\text { Meghalaya }\end{array}$ \\
\hline Article Info \\
\hline $\begin{array}{l}\text { Accepted: } \\
\text { 12 July 2019 } \\
\text { Available Online: } \\
\text { 10 August } 2019\end{array}$ \\
\hline \hline
\end{tabular}

A B S T R A C T

There is need of improved and innovative technology to raise production and productivity for enhancing efficiency of agriculture in NER. The Tribal Sub-Plan (TSP) is a strategy for Socio-economic development and livelihood security of tribal people of Meghalaya. The study was conducted to assess the socio-economic status of the respondents and to analyze the tangible and intangible benefits of the interventions in Rongram block of West Garo Hills distrct of Meghalaya. A total sample of 120 respondents was drawn from the different technological components. Simple Random Sampling technique was followed to select the respondents from the sampling frame. The salient findings of the study were about 80 per cent of the respondents belong to marginal and small farmers category of which marginal farmers occupies 50 per cent, which is also an indicator of poverty in the region. Majority of the respondent (75\%) depends only in farming in terms of livelihood generation activity. There is an increase (18.42\%) in average annual income of the TSP beneficiaries in the block after the interventions through various agricultural inputs, scientific cultivation practices and imparting capacity building programmes in selected villages of Rongram block, West Garo Hills. The cattle farmers reported that on an average, the cows produced 8 litres of milk everyday during the milking period. The milk was sold at ₹ 47per litre to Central Dairy Unit (Megha milk), West Garo Hills, Govt. of Meghalaya, which adds an imputed gross return per beneficiary ₹ 376 per day as a daily income. The average imputed return/ per year by the beneficiary was estimated to be of ₹ 112800 . It was observed that 85 per cent of beneficiaries are lacking of own capital which is followed by poor communication facilities $(75 \%)$ as constraints perceived by TSP beneficiaries. The study also recommends for up-scaling their livelihood and income which will act as model farmers of the area. The finding will help policy makers and administrators to find out several institution linkages with various community development programmes for its better implementation in convergence mode.

\section{Introduction}

Tribal Sub-Plan (TSP), a strategic policy initiative to secure overall development of the STs, was first introduced in the Fifth Five
Year Plan. The focus of TSP is on "securing budgetary allocations for tribal development at least proportionate to their population, in order to bring them at par with other sections of society and to protect them from 
exploitation." With the fast developing world, tribals required specific attention not only with monetary allocation but along with special interventions for their rapid socioeconomic development. The Tribal Sub-Plan envisages reducing gaps between the tribals and non-tribals in health, education, communication and other areas of basic amenities of life by providing legal and administrative support. The Sub-Plan also implements income generating schemes to boost the income of the tribals on a sustainable basis by taking into account their aptitude and skill.

Meghalaya in the North-East region is endowed with diverse agro-climatic conditions, rich genetic diversities, vast hydrological resources and pollution free environment that offer a great scope to develop agro-ecosystem a specific technological intervention for diversification of the Agriculture and allied activities viz. horticulture, animal husbandry and fisheries etc. The state displays a distinct ethnic, sociocultural and geographical identity. Meghalaya emerged as a full-fledged state within the union of India on 21st Jan 1972. It is tucked in the North East of India, covering an area of 22489 sq. $\mathrm{km}$. The State lies within $25^{\circ} 1^{\prime}$ and $26^{\circ} 5^{\prime}$ North latitudes and $85^{\circ} 49^{\prime}$ and $92^{\circ} 52^{\prime}$ East Longitudes. The temperature range is approximately 2 degree centigrade to 36 degree centigrade depending upon the altitude ranging between $300 \mathrm{mts}$ above mean sea level (MSL) to $2000 \mathrm{mts}$ above MSL. Meghalaya is amongst the highest rainfall areas in the world with an annual average rainfall of $11,000 \mathrm{~mm}$ during the period of 1980-91, predominantly mountainous, lying between the Brahmaputra valley in the North and the Surma valley (Bangladesh) in the South. The state has 11 districts viz., East Garo Hills, West Garo Hills, South Garo Hills, North Garo Hills, South West Garo, East Khasi Hills, West Khasi Hills, South
West Khasi Hills, Ri-bhoi, West Jaintia Hills and East Jaintia Hills. It has an area of 22,429 sq. $\mathrm{km}$ and a population of 29.67 lakhs where, 85.9 per cent of the population is tribal (Census, 2011). Out of the total population, 81 per cent of the inhabitants are depending on agriculture for their livelihood (GoM, 2015).

The economy of Meghalaya is basically agrarian as it is rural based with agriculture playing a predominant role in the state's economy. Since, 81per cent of the state's population depends on Agriculture, employment and income generation also depends on Agricultural developmental activities to a great extent. The State is yet to touch the National Level in economic and agricultural growth rate even after attaining full statehood more than twenty-five years ago. The State is slowly and steadily progressing in spite of the numerous constraints and limiting factors. Despite being endowed with vast natural resources and abundant biodiversity, the state has been experiencing distorted growth in agriculture and its allied sector. Watershed development, micro-irrigation/sprinkler, supply of quality seeds of improved cultivars and planting materials, promotion of allied enterprises/activities, development of appropriate rural infrastructures, land reforms, market reforms, backward and forward linkages with corporate/plantation agriculture, peoples Institutions (traditional knowledge, self-help groups, farm management committee) are the some suggested policy interventions to be undertaken for achieving the food and nutritional security and livelihood sustainability of rural households. By identifying target farmers and their locations; and infrastructural and institutional requirements this paper suggests pathways and policy choices for enhancing farmers' income(Pal, 2017). The tribal people earn by forestry, shifting cultivation, settle agriculture 
and horticulture, and industrial labour, animal husbandry, fishing, traditional commerce including handicraft. Most of the tribal, whether young or old have limited knowledge about modern horticultural methods and food production (Nidheesh, 2010). Adoption of new technology and sustainable utilization of resources can help farmers in minimizing the cost of production. New paradigm and challenges are needed for farmers of Meghalaya in solving the problem like recurrent price fluctuation, high marketing, storage and transportation cost, nonavailability of adequate storage facilities, post harvest losses and lack of competitive marketing system (Hatai, 2018).

Meghalaya comprises of various types of ethnic group namely the Khasi (Khynriam), Garo (Achik), Pnars (Jaintias) and other smaller tribes such as the Koch, Rabha, Lyngngametc, . The West Garo Hills district is pre-dominantly inhabited by the Garos, a tribe with a matrilineal society belonging to the Bodo family of the Tibeto-Burman race tribes. Other indigenous inhabitants are the Hajongs, Rabhas, Koches, Rajbansis, Meches, Kacharis and Dalus (Deka et al., 2009). The district is also inhabited by Bengalis, Assamese, Nepalese, Marwaries, Biharis and people from other parts of India. The ethnic group of people of Meghalaya still continues the practice of selecting a village headman also known as "Rangbah Shnong" among the Khasi and "Nokma" among the Garo communities as their leader(Kar, 1982). In this backdrop, a study entitled; "Enhancing Socio-Economic Status and Livelihood Security of Tribal Farmers of North East Hill States through Agricultural Interventions" was conducted at Rongram block of West Garo Hills district under Tribal Sub Plan (TSP) scheme, to reduce the socio-economic gap of some selected Garo tribal farm families (120 beneficiaries), who were selected based on certain criteria through Participatory Rural appraisal and Benchmark survey analysis.
Hence, in order to assess the outcome of the project in the study area an impact analysis was conducted on selected beneficiaries with the following objectives;

To assess the socio-economic status of the respondents and also to analyze the tangible and intangible benefits of the interventions

\section{Materials and Methods}

\section{Location of TSP intervention}

In Meghalaya, the study has been conducted at Rongram C.D. Block of West Garo Hills District during the crop year 2016-17. One block of the state was selected for intervention under the TSP project keeping in view the tribal population as well as the farming as a major domain of livelihood and income of the tribal farmers

\section{Selection of beneficiaries for interventions}

The baseline survey and Participatory Rural Appraisal (PRA) exercises were conducted in five villages namely Galwang Chidekgre, Dumitdikgre, Rangwalkamgre, Sanchonggre Edenbari in Rongram Block of West Garo Hills district of Meghlaya through the help of Nokmas (village headmen) of the respective villages. information on need based training and its beneficiaries of each of the selected villages were gathered and trainings were organized before the distribution of the agricultural inputs as well as construction of low cost poly-house, low cost mushroom unit, low cost vermi-compost units and Renovation of Ponds for the farmers of Rongram block of the West Garo Hills district of Meghalaya. Apart from structures of the inputs consist of construction of low cost poly-houses, low cost mushroom houses, low cost vermi-compost pits, various other animal components, horticultural seeds, saplings, agricultural seeds etc. The study initiatives facilitated different agricultural inputs and imparted trainings for capacity building to the tribal 
farmers of the five villages. As a part of follow up action, an impact assessment study was undertaken to analyze the tangible and non-tangible impact of the project. This will helpful for further scaling-up the project as well as to increase the number of villages under the intervention of the project.

\section{Selection of sample respondents}

The selection of respondents for impact assessment study was made on the basis of technological components provided under TSP to the selected beneficiaries in selected villages of Rongram block in West Garo Hills district of Meghalaya. A total sample of 120 respondents was drawn from the different technological components. Simple Random Sampling technique was followed to select the respondents from the sampling frame.

The data were collected from the sample TSP beneficiaries through personal interview method with the help of a semi-structured interview schedule covering all aspects. The schedule contains socio-economic, basic infrastructure, seasonal wise agricultural activities, inputs provided under TSP, decrease and increase in given input, income generated in cash and kind and reason behind the increase and decrease in given input. Primary data pertains for the crop year 201718 was collected.

\section{Analytical tools}

The analysis of data was performed in using Excel, Gretl and SPSS. For the logical inferences in impact assessment of TSP interventions in farms of beneficiaries, the statistical tools like frequency, mean and percentage were used.

\section{Results and Discussion}

Results of the impact analysis of the interventions in the study area have been presented in this chapter to satisfy the objectives of the study.

\section{Socio-economic characteristics of TSP farmers in sample villages of the study}

The socio-economic characteristics of farmers represent a complete picture of the existing situation of the study area. The major socio economic variables of TSP farmers are age, sex, education, caste, type of family, family size, farm size, dependency on farms, occupation and annual family income. It is found in the study that majority of the respondents (65\%) belongs to the Middle (3650 yrs) age group and the involvement of younger groups of the villagers is negligible $(15 \%)$ as it is evident from Table 1. This clearly indicates that younger generations of the Garo Tribal people in the block are not too much interested about farm activities. But, participation of women $(60 \%)$ in farm activities is considerably higher, probably because of matrilineal society.

Study also shows that 80 per cent of the respondents belong to marginal and small farmers category of which marginal farmers occupies 50 per cent, which is also an indicator of poverty in the region. Moreover, majority of respondents (65\%) having family size more than 5 members though 70 percent of the respondents have nuclear family status. Study also shows that 50 per cent households have annual income less than Rs.50,000/-, which is also relatively lesser in terms of cost of living in hilly region. Study also unfolds that 15 per cent of the respondents are still illiterate. But, overall educational status in the study area is relatively better than that of other poverty stricken areas in the country. One of the reasons of the poverty in the area is found in the study that majority of the respondent $(75 \%)$ depends only in farming in terms of livelihood generation activity (Table $1)$. 


\section{Change in annual income of the TSP beneficiaries}

Study came out with results that there is an increase $(18.42 \%)$ in average annual income of the TSP beneficiaries in the block after the interventions through various agricultural inputs, scientific cultivation practices and imparting capacity building programmes in selected villages of Rongram block, West Garo Hills as it is evident from Table 2. It was also observed from the study that farmers were cultivating local rice variety having low productivity. They were dependent on arecanut and tea plantation with traditional method of farm practices. TSP beneficiaries were engaged in pig rearing and keeping poultry birds for their domestic consumption. But after intervention of TSP, the beneficiaries were shown their interest in adopting scientific methods of farm practices in cultivating HYV rice varieties (CAU R-1), horticultural based farming. TSP beneficiaries have acquired knowledge and skill through various capacity building programmes on Dairy, Piggery, Poultry, Goatery, Vermicomposting and mushroom cultivation and taking such enterprise for income generation and livelihood. Table 3 shows that the respondents have more options for livelihood generation activities after the TSP intervention as compare to before intervention, which probably contributed in the increase in the average annual income of the respondents.

\section{Impact of technological intervention through TSP}

The tangible and intangible benefits are estimated during the impact assessment study. As various agricultural technology components were distributed to the selected beneficiaries of selected villages. Hence, impact (after intervention of TSP) of field crop (rice) and horticultural crops such as Tomato, pea, ladies finger, ginger, chilli, French beans, plantation, livestock like cattle, pig, goat, and poultry is described as under their respective head. Before the interventions of TSP, the people of the villages were growing the local rice varieties which give less production and are susceptible to diseases and pest infestation. With the execution of TSP, the farmers of the area were provided seeds of improved rice varieties known as CAUR1. This variety is a rain-fed and wetland variety with average yield of 6.0-6.5t per ha. It performs best under low application of fertilizer and has a very high brown rice recovery. It is also tolerant to rice blast, bacterial leaf blight, submergence up to 7 days and late sowing upto July end. Therefore, with the introduction of this rice variety the beneficiaries were able to harvest an average production of 15.8 qtl rice and an average gross returns of ₹ 23700 per ha which was reported to be more than the local rice varieties. CAU R-1variety has attracted the farmers to adopt in larger area. Farmers were very much satisfied with the performance and economic returns from the cultivation of CAUR1 variety (Table 4).

The major advantage of the Garo Hills region is its suitability for growing vegetable crop owing to its climatic condition. Under TSP the beneficiary farmers were provided tomato seeds. The average gross returns from tomato were reported of ₹ 600 with an average yield of $20 \mathrm{~kg}$ per season per beneficiaries. Under TSP, the beneficiary farmers were provided pea seed. The average yield per household was reported and estimated to be of $25 \mathrm{~kg}$ which fetched and added of ₹ 1250 as the average gross return per annum per beneficiaries. Another vegetable seed which was distributed to the beneficiaries was ladies finger. The average production of the crop was $4 \mathrm{~kg}$ with average gross return of ₹ 120 . 
Table.1 Socio-economic characteristics of TSP Beneficiaries in sample villages of Rongram Block, West Garo Hills

\begin{tabular}{|c|c|c|c|}
\hline \multirow{3}{*}{$\begin{array}{l}\text { SI. No } \\
1\end{array}$} & \multirow[b]{2}{*}{ Particulars } & \multicolumn{2}{|c|}{$(\mathrm{N}=120)$} \\
\hline & & Frequency & Percentage $(\%)$ \\
\hline & \multicolumn{3}{|l|}{ Age group } \\
\hline & Young (upto 35 yrs) & 18 & 15.0 \\
\hline & Middle (36-50 yrs) & 78 & 65.0 \\
\hline & Old (more than 51 yrs) & 24 & 20.0 \\
\hline \multirow[t]{3}{*}{2} & \multicolumn{3}{|l|}{ Gender } \\
\hline & Male & 48 & 40.0 \\
\hline & Female & 72 & 60.0 \\
\hline \multirow[t]{5}{*}{3} & Size of Land holdings (Farm Size) & & \\
\hline & Marginal (Less than 1 ha.) & 60 & 50.0 \\
\hline & Small (1- 2 ha) & 36 & 30.0 \\
\hline & Medium (2-4 ha) & 24 & 20.0 \\
\hline & Large (More than 4 ha.) & 0 & 0.0 \\
\hline \multirow[t]{4}{*}{4} & Family size & & \\
\hline & $\leq 4$ members & 42 & 35.0 \\
\hline & 5-9 members & 66 & 55.0 \\
\hline & $\geq 10$ members & 12 & 10.0 \\
\hline \multirow[t]{3}{*}{5} & Type of Family & & \\
\hline & Joint & 36 & 30.0 \\
\hline & Nuclear & 84 & 70.0 \\
\hline \multirow[t]{5}{*}{6} & Annual income (Rs.) & & \\
\hline & Upto Rs. $30,000 /-$ & 18 & 15.0 \\
\hline & Rs.30,001- Rs.50,000/- & 42 & 35.0 \\
\hline & Rs.50,001- Rs.70,000/- & 36 & 30.0 \\
\hline & Above Rs.70,001/- & 24 & 20.0 \\
\hline \multirow[t]{6}{*}{7} & \multicolumn{3}{|l|}{ Educational status } \\
\hline & Illiterate & 18 & 15.0 \\
\hline & Primary & 30 & 25.0 \\
\hline & Middle & 48 & 40.0 \\
\hline & Secondary & 18 & 15.0 \\
\hline & Graduate $\&$ above & 6 & 5.0 \\
\hline \multirow[t]{5}{*}{8} & \multicolumn{3}{|l|}{ Occupation } \\
\hline & Farming alone & 90 & 75.0 \\
\hline & Farming + Agriculture related occupation & 24 & 20.0 \\
\hline & Farming + Services & 0 & 0.0 \\
\hline & Agricultural labour & 6 & 5.0 \\
\hline \multirow[t]{3}{*}{9} & Depending on farming / land & & \\
\hline & Fully dependent & 90 & 75.0 \\
\hline & Partially dependent & 30 & 25.0 \\
\hline
\end{tabular}

Source: Own Field Survey, (2018) 
Table.2 Change in annual income of TSP Beneficiaries

\begin{tabular}{|l|c|c|c|}
\hline & $\begin{array}{c}\text { Before } \\
\text { Intervention } \\
\text { (TSP) }\end{array}$ & $\begin{array}{c}\text { After } \\
\text { Intervention } \\
\text { (TSP) }\end{array}$ & $\begin{array}{c}\text { Per cent } \\
\text { Increase }\end{array}$ \\
\hline $\begin{array}{l}\text { Avg. Annual income } \\
\text { (Rs.) }\end{array}$ & 38000 & 45000 & 18.42 \\
\hline
\end{tabular}

Table.3 Main crops/farm animals /enterprise of tsp beneficiaries

\begin{tabular}{|l|l|l|}
\hline Domains & $\begin{array}{l}\text { Before Intervention } \\
\text { (TSP) }\end{array}$ & After Intervention (TSP) \\
\hline $\begin{array}{l}\text { Main Crops/ } \\
\text { Enterprise }\end{array}$ & $\begin{array}{l}\text { Local Rice, } \\
\text { Areca nut, Tea }\end{array}$ & $\begin{array}{l}\text { HYV Rice(CAU R1), Arecanut, Tea, } \\
\text { Vegetables, } \\
\text { Dairy, Piggery, Poultry, Mushroom, } \\
\text { Vermi-composting }\end{array}$ \\
\hline Farm Animals & Poultry Birds, Pig & Cow, Goat, Pig, Poultry Birds \\
\hline
\end{tabular}

Table.4 Impact of Paddy Cultivation (CAU R-1)

\begin{tabular}{|l|l|l|l|l|l|l|l|}
\hline $\begin{array}{l}\text { Sl. } \\
\text { No. }\end{array}$ & Field Crop & \multicolumn{2}{|c|}{ Avg. Area (ha) } & \multicolumn{2}{|c|}{$\begin{array}{c}\text { Avg. Yield } \\
\text { (qtl/ha) }\end{array}$} & \multicolumn{2}{|c|}{$\begin{array}{c}\text { Imputed gross return / } \\
\text { beneficiary/annum (Rs./ha) }\end{array}$} \\
\cline { 3 - 8 } & & $\begin{array}{c}\text { Before } \\
\text { TSP }\end{array}$ & $\begin{array}{c}\text { After } \\
\text { TSP }\end{array}$ & $\begin{array}{c}\text { Before } \\
\text { TSP }\end{array}$ & $\begin{array}{c}\text { After } \\
\text { TSP }\end{array}$ & Before TSP & After TSP \\
\hline $\mathbf{1}$ & Rice & 0.43 & 0.66 & 12.5 & 15.8 & 18750 & 23700 \\
\hline
\end{tabular}

returns from horticultural crops

Table.5 Returns from horticultural crops under TSP

\begin{tabular}{|l|l|c|c|}
\hline Sl. No. & Horticultural Crop & $\begin{array}{c}\text { Average quantity } \\
(\mathbf{K g})\end{array}$ & $\begin{array}{c}\text { Imputed Gross Returns / } \\
\text { Beneficiary(₹) }\end{array}$ \\
\hline $\mathbf{1}$ & Tomato & $20 \mathrm{~kg}$ & 600 \\
\hline $\mathbf{2}$ & Pea & $25 \mathrm{~kg}$ & 1250 \\
\hline $\mathbf{3}$ & Ladies finger & $4.0 \mathrm{~kg}$ & 120 \\
\hline $\mathbf{4}$ & Ginger & $65 \mathrm{~kg}$ & 1300 \\
\hline $\mathbf{5}$ & Chilli & $10 \mathrm{~kg}$ & 200 \\
\hline $\mathbf{6}$ & French Bean & $18 \mathrm{~kg}$ & 720 \\
\hline
\end{tabular}


Table.6 Returns from various interventions under TSP project

\begin{tabular}{|l|l|c|c|}
\hline SI. No. & Domains & Average quantity & $\begin{array}{c}\text { Imputed gross return / } \\
\text { beneficiary/annum } \\
\text { (₹ ) }\end{array}$ \\
\hline \multicolumn{2}{|l|}{ Returns from Livestock } & 8 litre/day & 112800 \\
\hline $\mathbf{1}$ & Cattle & 6 piglet & 15000 \\
\hline $\mathbf{2}$ & Pig & 3 goats+3kids & 5000 \\
\hline $\mathbf{3}$ & Goat & $\begin{array}{c}\text { 3 poultry bird } \\
60 \text { eggs }\end{array}$ & 1500 \\
\hline $\mathbf{4}$ & Poultry & & \\
\hline \multicolumn{2}{|l|}{ Returns from Mushroom Cultivation } & $10 \mathrm{~kg}$ & 4000 \\
\hline $\mathbf{1} \quad$ Oyster & & 1000 \\
\hline Returns from Polyhouse & Vegetable Seedlings & 1000 seedlings & 900 \\
\hline $\mathbf{1}$ & Vegetables & $30 \mathrm{~kg}$ & \\
\hline $\mathbf{2}$ & & & \\
\hline
\end{tabular}

Table.7 Major constraints in effective implementation of TSP

\begin{tabular}{|c|c|c|c|}
\hline Sl. No. & Rating & Particulars & Percentage \\
\hline \multirow[t]{4}{*}{1} & \multirow[t]{4}{*}{ Most Severe } & Lack of own capital & 85.0 \\
\hline & & Poor communication facilities & 75.0 \\
\hline & & Inadequate availability of raw material & 40.0 \\
\hline & & Inadequate family labour & 25.0 \\
\hline \multirow[t]{4}{*}{2} & \multirow[t]{4}{*}{ Severe } & Complicated procedure of getting loan & 80.0 \\
\hline & & High cost of technology & 60.0 \\
\hline & & Non-availability of Insurance facilities & 35.0 \\
\hline & & Lack of change agent & 25.0 \\
\hline \multirow[t]{3}{*}{3} & \multirow[t]{3}{*}{ Not Severe } & $\begin{array}{l}\text { Inadequate income generation from primary } \\
\text { activity }\end{array}$ & 40.0 \\
\hline & & Lack of awareness on improved technology & 25.0 \\
\hline & & Lack of religious and caste support & 10.0 \\
\hline
\end{tabular}

The total percentage across each respondents is not added up to 100 due to multiple or no response.

The average quantity harvested from ginger by the beneficiary households was $65 \mathrm{~kg}$ with an imputed gross return of ₹ 1300 per beneficiary per season. Among the major spice crops, chilli is one of the emerging crops in the state and seeds were distributed under TSP. The average gross returns from chili were reported of ₹ 200 with an average yield of $10 \mathrm{~kg}$ per season per beneficiaries. The beneficiary farmers grow this spice crop in small piece of land and sale them in Rongram and Tura market to get returns. The average quantities harvested from french beans by the beneficiary households was 18 $\mathrm{kg}$ with an imputed gross return of ₹ 720 per beneficiary per season (Table 5). 


\section{Returns from Livestock}

Dairy farming is one of the integral parts of Integrated Farming System. But, unfortunately dairy farming practices is not that much popular in Garo Hills. Due to lack of improved breed in the area and lack of knowledge of improved dairy farming practices, it was comparatively less remunerative for the farmers in Garo Hills. The cattle farmers reported that on an average, the cows produced 8 litres of milk everyday during the milking period. The milk was sold at ₹ 47per litre to Central Dairy Unit (Megha milk), West Garo Hills, Govt. of Meghalaya, which adds an imputed gross return per beneficiary ₹ 376 per day as a daily income. The average imputed return/ per year by the beneficiary was estimated to be of ₹ 112800 (Table 6). Here, notable was that the beneficiary encouraged through cattle rearing and its accrued benefits, he purchased another cow to enlarge his dairy business. Besides these, the apparent non-tangible benefits realized by the beneficiaries was consumption of milk which was completely absent before the initiation of the TSP. Milk is always considered as complete food and daily consumption of milk human healthy which save the cost of medicines and enhance the human work efficiency. The analysis has not taken into consideration the FYM which has tangible and non-tangible benefits to the farm. Therefore, it was found and realized by the beneficiaries that cattle rearing not only benefitted as tangibly but also benefitted intangibly. Pig farming is the major livestock enterprise and main domain of livelihood and income of the tribal of the state. As a part of diet pork is a delicacy of the people in the state. During the survey beneficiaries reported that the piglet have been sold after getting the sufficient size and maturity in age and new piglets have been brought in their den. On an average, the imputed gross returns from given piglets was estimated of ₹ 15000 per beneficiaries (Table 6). The goat farming is an emerging enterprise among the tribal. It requires relatively less care and space to rear. It can survive easily on vegetation/grass and small quantity of feed. Among the goat rearing beneficiaries some of them could multiple and earned gross returns of ₹ 5000/ per beneficiaries per year (Table 6). Many of the beneficiaries could not multiply the same due to non-awareness of its management. Some of them reported non-availability of male goat for further breeding/multiplying the same. Therefore, it is suggested that the more pair of male and female goat should be given in future distribution of goat. Poultry is one of the fastest growing segments of the agricultural intervention under TSP. Poultry was mainly reared by the farmers for eggs and meat. On an average, the distributed poultry laid around 60 eggs per year. The average imputed return/ per year by the beneficiary was estimated to be of ₹ 1500 (Table 6).

\section{Constraints perceived by TSP beneficiaries}

The constraints as perceived by TSP beneficiaries are presented in table 7 . It was observed that 85 per cent of beneficiaries are lacking of own capital which is followed by poor communication facilities (75 \%). Complicated procedure of getting loan, High cost of technology and Non-availability of Insurance facilities are the sever constraints faced by the TSP beneficiaries. Farmers have expressed that there is no sever in inadequate income from primary activity (40\%), lack of awareness on improved technology (25\%).

In conclusions, Tribal Sub-Plan (TSP), a strategic policy initiative to secure overall development of tribal population. The Tribal Sub-plan has left a positive tangible and intangible impact on tribal community of the state. The livestock like cattle, pig, poultry, and goat were found very emerging inputs for enhancing the livelihood and income of the 
tribal farmer in the state. Both tangible and intangible benefits were realized and reported by the TSP beneficiaries. Moreover, the study has emphasized on enhancing the extension activities in the selected villages for selected beneficiaries that has left the positive impact on livelihood and income of the farmers. The study also recommends for up-scaling their livelihood and income which will act as model farmers of the area. The finding will help policy makers and administrators to find out several institution linkages with various community development programmes for its better implementation in convergence mode. The study concluded that positive change had occurred among the respondents in terms socio economic status and livelihood security after commencement of TSP in the study area. So it can be said that TSP achieved one of its desired goals to enhance socio economic status and livelihood security of the tribal people.

\section{References}

Deka D and Sarma G C (2009). Traditonal used herbs in the preparation of ricebeer by the Rabha tribe of Goalpara district, Assam. Indian Journal Traditional Knowledge. 9(3): 459-62.

Hatai, L. D. 2018. Cost of Cultivation and Economic Returns Analysis of Cashewnut in West Garo Hills of Meghalay, Economic Affairs, 63(2): 399-405.

Kar, P. C. (1982). 'The Garos in Transition'. publ: Cosmo Publications, New Delhi. Pp-22- 32, 44-61.

Nidhees, K. B. 2010. Agriculture Knowledge and Perception of Tribal Communities. Indian Journal of Traditional Knowledge. 9(3): 531-535.

Pal, S. 2017. Enhancing Farmers' Income: Who to Target and How? Policy Paper30 ,

ICAR -National Institute of Agricultural Economics and Policy Research (NIAP), New Delhi.

Statistical Handbook of Meghalaya (GOM). 2015. Ministry of Statistics and Programme Implementation, Govt. of India.

\section{How to cite this article:}

Lakshmi Dhar Hatai and Noren Singh, K. 2019. Socio-Economic Status and Benefits of Agricultural Interventions of Tribal Farmers in West Garo Hills of Meghalaya, India. Int.J.Curr.Microbiol.App.Sci. 8(08): 1554-1563. doi: https://doi.org/10.20546/ijcmas.2019.808.183 